\title{
Temporal dynamics in the effectiveness of seed dispersal by birds visiting a tropical tree
}

\author{
Marco A. Pizo ${ }^{1, *}$ and Paulo H. S. A. Camargo ${ }^{2}$ \\ ${ }^{1}$ Department of Zoology, São Paulo State University (UNESP), Institute of Biosciences, Rio Claro, Brazil \\ 2 Graduate Program in Ecology and Biodiversity, São Paulo State University (UNESP), Institute of Biosciences, Rio Claro, Brazil \\ (Received 5 December 2017; revised 12 June 2018; accepted 13 June 2018)
}

\begin{abstract}
Seed dispersal effectiveness (SDE) is related to the role of seed dispersal agents in realizing the reproductive potential of plants through seed dispersal and subsequent plant recruitment. The SDE of a given seed disperser may vary spatially and temporally, with important implications for our understanding of the mutualistic relationships involving plants and frugivores. Here we observed 22 frugivorous bird species visiting an individual tree (Cabralea canjerana) over a 9-y period in a fragment of Atlantic forest in south-eastern Brazil to document the temporal variation in SDE. The quantitative (that takes into account the frequency of feeding visits to the focal plant and the number of fruits removed per visit) and qualitative (that considers the probability of seed deposition on a suitable site for plant recruitment) components of SDE varied in two and one order of magnitude both among bird species and among years within bird species, respectively. As a result, the SDE of bird species fluctuates over the years, especially for a migratory species that is the main seed disperser of $C$. canjerana (Chivi vireo Vireo chivi) whose quantitative component (i.e. the product of visit and fruit intake rates) varied from 3.0 to 7.1. This study illustrates the dynamic nature of the seeddispersal environment to which a plant is subjected to over the course of its life, which has important consequences for the plant's individual fitness.
\end{abstract}

Key Words: agonistic interactions, Atlantic forest, Cabralea canjerana, forest fragmentation, frugivory, fruit chemistry

\section{INTRODUCTION}

Individual trees may live for centuries and during their long life they interact with a multitude of other organisms. The effects these organisms exert upon trees may vary temporally as intrinsic and extrinsic factors relevant to the interaction vary during the tree's lifespan (Herrera 1985). The temporally dynamic nature of interspecific interactions has consequences for the plant's fitness, population persistence and, in an evolutionary perspective, for the evolution of plant-animal interactions (Thompson 2005).

Temporal variation in the interactions between animaldispersed plants may occur as a response to fluctuations in the composition and relative abundances of seed dispersers (Herrera 1998, Tellería et al. 2008). Since the seed dispersal effectiveness (SDE, sensu Schupp 1993) of different animals may differ considerably, temporal fluctuations in the composition and relative abundances of seed dispersers may affect the reproductive success of

* Corresponding author. Email: pizo@rc.unesp.br individual plants (Yamazaki et al. 2016). Among extrinsic factors potentially influencing SDE are the agonistic interactions among plant visitors affecting quantitative aspects of the SDE such as time spent on fruiting plants and fruit feeding rates (French \& Smith 2005). Intrinsic factors that may fluctuate over time and are relevant to SDE are fruit size and fruit chemistry, both potentially influencing fruit choice by frugivores (Blendinger et al. 2015, Wheelwright 1993). If directional and widespread in the plant population, such fluctuations may lead to long-lasting changes that affect plant recruitment and plant traits relevant for the seed dispersal process (e.g. seed size) in surprisingly short time spans (Galetti et al. 2013).

The SDE framework represents a valuable approach for assessing the temporal dynamics of a given seed dispersal assemblage since it permits the evaluation of how good each dispersal agent is in realizing the reproductive potential of plants through seed dispersal and subsequent plant recruitment (Schupp 1993). SDE has both quantitative and qualitative components. While quantitative components refer to the quantity of seeds 
removed from the plant, which is influenced by factors such as the plant visitation rates of potential seed dispersers and their probability of removing a seed, the qualitative component is related to the probability that a removed seed generates a plant recruit, which is influenced by the treatment the seed receives in the disperser's gut and the site of seed deposition (Schupp 1993). Both the quantitative and qualitative components may fluctuate over time resulting in temporal variation in SDE (Schupp et al. 2010).

While the spatial variation in seed dispersal has been investigated in detail (Nathan \& Muller-Landau 2000, Tellería et al. 2014), temporal variation has received far less attention (Jordano 1995, McConkey et al. 2014). The aim of this study was to investigate the variation in SDE of bird species visiting an individual tree of Cabralea canjerana (Meliaceae) over a 9-y period. We explore the possibility of temporal variation in intrinsic (fruit size and chemistry) and extrinsic (abundance and agonistic interactions of fruit-eating birds) factors influencing SDE. Specifically, we hypothesized that the SDE of bird species, particularly the quantitative component, will be positively influenced by their abundances, while the rate of agonistic interactions will negatively influence SDE.

\section{METHODS}

The focal tree (10 m height) was located at the very edge of Mata de Santa Genebra (22 $49^{\prime} \mathrm{S}, 47^{\circ} 06^{\prime} \mathrm{W}, 640 \mathrm{~m}$ asl), a 250-ha fragment of semideciduous Atlantic forest (sensu Morellato \& Haddad 2000) located in Campinas, south-eastern Brazil. The fragment is surrounded by residential areas and sugar cane plantations.

Cabralea canjerana is a bird-dispersed tree species occurring from Costa Rica to southern Brazil and northern Argentina (Pennington 1981). Fruiting at the study site occurs from October to December. Fruits are globose capsules that dehisce to expose from one to six diaspores (the unit of dispersal) with mean diameter of $7.8 \pm 0.5$ $\mathrm{mm}$ (range 6.5-10.0 $\mathrm{mm}, \mathrm{n}=264$ ); each diaspore (for simplicity simply called fruit hereafter) has one or two seeds surrounded by a lipid-rich orange aril (Pizo 1997).

One of us (MAP) observed the tree with binoculars from a concealed position $10 \mathrm{~m}$ from the tree that permitted a totally unobstructed view of the crown. Observations were made in non-consecutive days so as to span the whole fruiting seasons of 1990, 1993, 1995 and 1999 for a total of $14.5,17.5,15$ and $15 \mathrm{~h}$, respectively. During each year, from eight to 15 observation sessions starting always at sunrise and lasting from 25 to $135 \mathrm{~min}$ were made. We visually estimated the fruit crop of the focal tree in the study years as over a thousand fruits. Although the tree fruited in some of the intervening years, fruit crops then were of a few dozen fruits. Upon each feeding visit (i.e. a visit by an individual bird or conspecific group that actually feed on fruits) we noted (1) the bird species; (2) the number of fruits taken during the entire visit (i.e. effectively ingested, not considering fruits dropped beneath the tree or carried away in the beak. Birds that carried fruits in the beak normally did not eat them whole, but pecked portions of the aril and dropped the seeds. Such partially eaten fruits are rapidly attacked by fungi and we assume had a negligible chance of producing a seedling); (3) any intra- or interspecific agonistic interactions (i.e. when a bird chased another bird displacing it from the tree or the fruit it was about to eat); and (4) the direction faced by the bird after leaving the tree, either the forest fragment or the adjacent matrix formed by residential blocks. To record item (2) above when several birds were concomitantly at the tree, the observer focused on an individual bird until it was lost from sight or left the tree, when another individual was then followed.

The quantitative component of seed dispersal effectiveness was calculated by multiplying visitation and fruit consumption rates. The probability of seed deposition in the forest corresponded to the qualitative component. We considered the habitat faced by a bird after leaving the focal tree as a likely place for the deposition of seeds (see Jordano \& Schupp 2000 for the same rationale). Contrasting with the forest, the urbanized matrix adjacent to the focal tree was clearly a habitat where a dispersed seed has almost no chance of producing an adult tree. The qualitative component as defined above was obtained only in the last two study years, 1995 and 1999.

To evaluate the relative importance of visitation and fruit consumption rates on the quantitative component, we performed a multiple regression of each subcomponent on the quantitative component with Img estimates and calculated the bootstrapped confidence intervals for the relative contributions using package relaimpo (Groemping 2006) in the R program version 3.3.1.

To correlate visitation rate to the focal tree with bird abundances, we surveyed a 250-m line transect set along the border of the forest fragment and passing by the focal tree. Every bird seen or heard at unlimited distances from both sides of the transect was recorded. Surveys were made immediately after the end of frugivory observations and lasted for 30-55 min. Eight surveys were made in 1990 and 1999 for a total 6.4 and $4.1 \mathrm{~h}$, respectively. Surveys of a given year were pooled to correlate with the total visitation rate of each bird species for that year. We express bird abundance as the number of records per hour of survey. Bird nomenclature follows Piacentini et al. (2015).

Annual variation in diaspore size and fruit chemistry was assessed by collecting recently opened fruits directly from the trees and measuring the largest diameters of diaspores with a calliper to the nearest $0.1 \mathrm{~mm}$. In 1993 
Table 1. Bird visitation parameters and fruit traits of the Cabralea canjerana tree observed in a fragment of semideciduous Atlantic forest in south-eastern Brazil. Chemical analyses of fruits were performed only in 1993 and 1995. Sample sizes of diaspore diameter are indicated in parentheses. Values for aril chemistry refer to percentages in a dry mass basis.

\begin{tabular}{|c|c|c|c|c|c|c|c|}
\hline \multirow[b]{2}{*}{ Year } & \multirow{2}{*}{$\begin{array}{l}\text { Number } \\
\text { of bird } \\
\text { species }\end{array}$} & \multirow{2}{*}{$\begin{array}{c}\text { Visit rate } \\
\text { (visits } \\
\mathrm{h}^{-1} \text { ) }\end{array}$} & \multirow{2}{*}{$\begin{array}{l}\text { Rate of agonistic } \\
\text { interactions } \\
\left.\text { (chases h }{ }^{-1}\right)\end{array}$} & \multirow{2}{*}{$\begin{array}{l}\text { Diaspore mean } \\
\text { diameter } \pm S D \\
\quad(\mathrm{~mm})\end{array}$} & \multicolumn{3}{|c|}{ Aril chemistry (\%) } \\
\hline & & & & & Water & Lipids & Protein \\
\hline 1990 & 13 & 10.9 & 7.6 & $7.9 \pm 0.5(26)$ & - & - & - \\
\hline 1993 & 15 & 14.6 & 0.6 & $7.7 \pm 0.4(63)$ & 19.5 & 73.8 & 7.5 \\
\hline 1995 & 15 & 22.1 & 1.1 & $7.7 \pm 0.5(99)$ & 38.5 & 74.7 & 7.9 \\
\hline 1999 & 20 & 12.4 & 0.9 & $8.0 \pm 0.6(76)$ & - & - & - \\
\hline
\end{tabular}

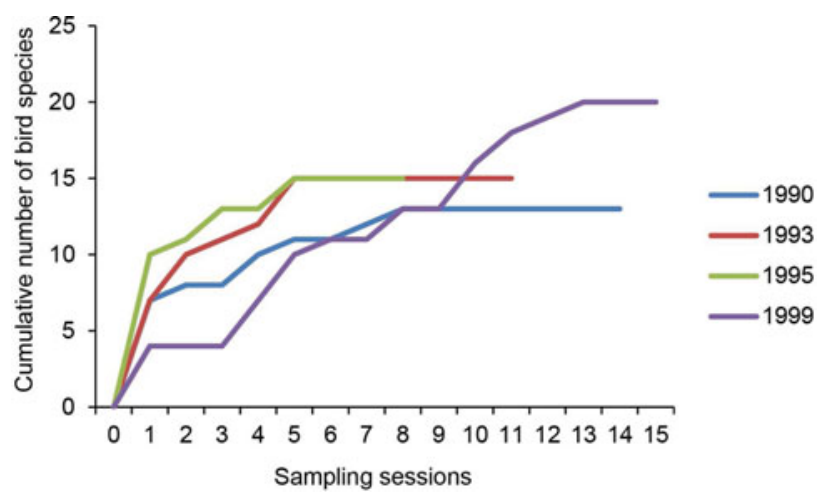

Figure 1. Cumulative number of bird species visiting a fruiting Cabralea canjerana tree during observation sessions made in four years in a fragment of semideciduous Atlantic forest in south-eastern Brazil. Observation sessions were carried out on non-consecutive days and lasted from 25 to $135 \mathrm{~min}$.

and 1995 arils of these diaspores were manually removed and frozen for chemical analyses. Lipid content was determined with the method described by Bligh \& Dyer (1959), and proteins by the Kjeldahl method (Horwitz 1975). Water was quantified by evaporation of samples at $60^{\circ} \mathrm{C}$ until a constant weight.

\section{RESULTS}

A total of 22 bird species visited the tree, varying from 13 to 20 species per year (Table 1; Appendix 1). The cumulative number of bird species recorded apparently stabilized in all study years, indicating that we were able to sample most of the species visiting the focal tree (Figure 1). The chivi vireo Vireo chivi was always the most frequent visitor, followed by flycatchers, either Myiodynastes maculatus or Myiarchus spp. depending on year (Appendix 1). The between-year similarity in the assemblages of visiting species was high, ranging from 0.79 to 0.94 (Morisita's index of similarity), indicating a low temporal species turnover.

Among the subcomponents forming the quantitative component, visitation rate varied more than fruit con- sumption rate (Appendix 1), and was the variable that contributed the most for variation in the quantitative component in all study years (Figure 2). The lowest visitation rate occurred in 1990, while in 1995 the visitation rate more than doubled (Table 1). Visitation rate of each bird species was correlated with its abundance in 1999 (Pearson's correlation: $\mathrm{r}=0.48, \mathrm{n}=21, \mathrm{P}=0.03$; abundance range: $0.0-1.6$ records $\mathrm{h}^{-1}$ ), but not in 1990 $(\mathrm{r}=-0.06, \mathrm{n}=21, \mathrm{P}=0.78$; abundance range: $0.0-2.7$ records $\mathrm{h}^{-1}$ ).

Inter- and intraspecific agonistic interactions occurred at similar frequencies $(52.6 \%$ and $47.4 \%$, respectively, $\mathrm{n}=150$ ). The greatest rate of agonistic interactions occurred in 1990 (Table 1), mainly because of the palebreasted thrush Turdus leucomelas, an aggressive species involved in $62 \%$ of the interactions recorded in 1990 $(\mathrm{N}=110)$, always as a dominant species. Following the sharp decrease in the visitation rate of T. leucomelas in subsequent years (Appendix 1), its participation in agonistic interactions dropped to zero in $1993(\mathrm{n}=11)$ and $1995(\mathrm{n}=16)$, and $7.7 \%(\mathrm{n}=13)$ in 1999.

The temporal trajectories of bird species in the quantitative landscape defined by visitation and fruit consumption rates showed several cases of species changing positions among isolines, with the noteworthy case of $V$. chivi that went up and down in the quantitative landscape over the years (Figure 3a). Changing positions were also observed in the SDE landscape defined by quantity and quality components, with several species with decreasing effectiveness between 1995 and 1999 driven by decreases affecting mainly the quantitative component (e.g. visitation rate in Chiroxiphia caudata), the qualitative component (e.g. Empidonomus varius) or both (M. maculatus) (Figure 3b; Appendix 1).

The diameter, lipid and protein content of diaspores varied slightly over the years, but the water content was much higher in 1995 than in 1993 (Table 1).

\section{DISCUSSION}

We have shown that the SDE of potential seed dispersers of a single tree fluctuates over the years. As such, 


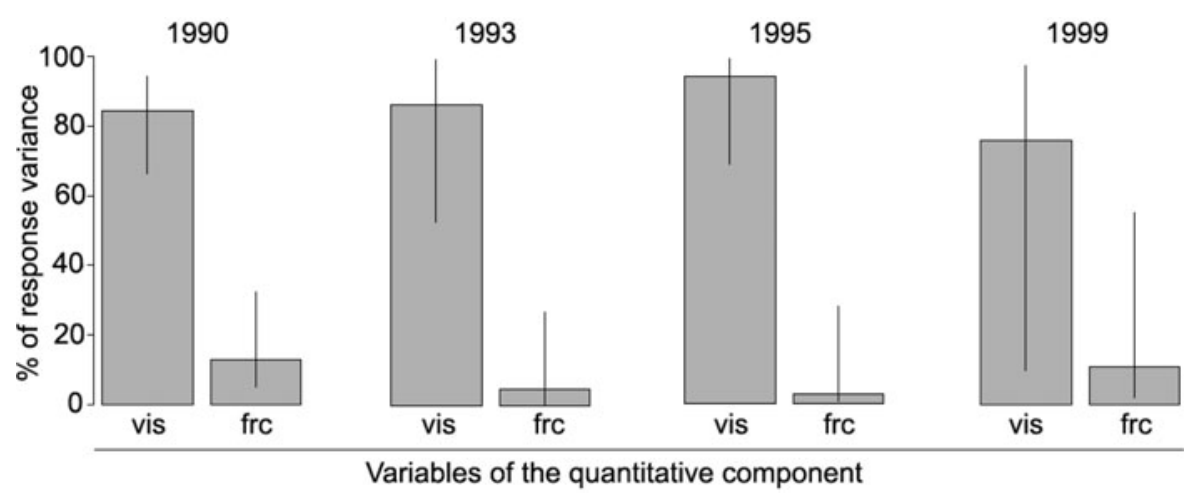

Figure 2. Relative importance of visitation (vis) and fruit consumption rates (frc) to the quantitative component of seed dispersal of Cabralea canjerana in different years in a fragment of semideciduous Atlantic forest in south-eastern Brazil. Bars indicate the relative contribution of each variable to the total variance across frugivore bird species in the quantitative component: $1990, \mathrm{R}^{2}=97.3 \% ; 1993, \mathrm{R}^{2}=91.1 \% ; 1995, \mathrm{R}^{2}=96.4 \% ; 1999$, $\mathrm{R}^{2}=86.4 \%$. Bar plots represent the lmg estimates of these relative contributions, with their bootstrapped confidence intervals.

this study illustrates the dynamic nature of the seed dispersal environment to which a tree is subjected to over the course of its life. We explored factors that might explain variation in SDE, namely bird abundances and agonistic interactions involving fruit-eating birds. Plants depending on migratory species for seed dispersal (e.g. certain Central American plants, Howe \& De Steven 1979) are likely to suffer intense temporal fluctuations in reproductive outcomes since migratory bird species are particularly prone to annual fluctuations in abundance (Blake \& Loiselle 1991, Jordano 1995). As a result, the contribution of migratory birds to seed dispersal may vary greatly among years, as illustrated by $V$. chivi, quantitatively the main disperser of $C$. canjerana seeds whose position in the quantitative component biplot fluctuated widely (Figure 3a). Such temporal fluctuation in abundance may be exacerbated under a scenario of climate change that may particularly affect migratory birds (Saino et al. 2011).

In all years, the variation in the quantitative component was driven at lower or higher extent by the variation in visitation rate compared with fruit consumption per visit (Figure 2), meaning that the variation is mainly along the x-axis of the effectiveness landscape of the quantitative component (Figure 3a). The abundance of birds is often correlated with their frequency of visits to fruiting plants (Jordano 1995). In our study this relationship only held in 1999, but not in 1990 . We suspected that the defence of the focal tree by T. leucomelas in 1990 accounted for the uncoupling between bird abundance and visitation rate that year. Frugivorous birds rarely defend fruiting plants (Male \& Roberts 2002), but in $1990 \mathrm{~T}$. leucomelas actively chased other potential seed dispersers from the focal tree, which increased the rate of agonistic interactions in comparison to other years (Table 1). As a result, the contribution of T. leucomelas to the quantity of seeds removed peaked in 1990 when it partially monopolized the tree (Figure 3a). In subsequent years, when T. leucomelas did not defend the tree, its contribution to the quantity of seeds removed from the tree dropped sharply (Figure 3a). We can only speculate about why T. leucomelas defended the tree in only one of the four study years. Decreases in the species abundance (from 0.6 records $\mathrm{h}^{-1}$ in 1990 to 0.2 records $\mathrm{h}^{-1}$ in 1999) and the lack of alternative food resources in 1990 are among the potential causes. But the phenomenon may simply have been caused by the presence of a particularly aggressive bird that monopolized the tree in 1990. Thus, even apparently unimportant events, as the establishment of a feeding territory by a bird, may alter the SDE of the whole assemblage of potential seed dispersers visiting a fruiting tree.

Apart from seed-disperser abundance, other factors to explain the temporal variation in SDE are variation in fruit size and chemistry. Fruit size varied slightly among years in our tree (Table 1), but even such small variation may be important if morphological constraints impede potential seed dispersers to remove the fruits. This is the case of $V$. chivi that, though being the most important remover of $C$. canjerana seeds, drops $30 \%$ of the fruits handled under parent trees (Pizo 1997). Fruits dropped have diameters that exceed the gape width of $V$. chivi (7.6 mm), which is thus unable to swallow them. Therefore, even a small annual variation in fruit size may influence the SDE of the main seed disperser of $C$. canjerana, consequently changing the relative importance of other bird species as seed dispersers.

A greater annual variation occurred in the chemical composition of fruits, especially in water content (Table 1). Although the role played by small variation in fruit chemistry upon fruit removal is largely unknown, frugivorous birds are choosy enough to detect subtle differences in fruit nutrient concentration (Schaefer et al. 2003) and may potentially use this ability to choose one 

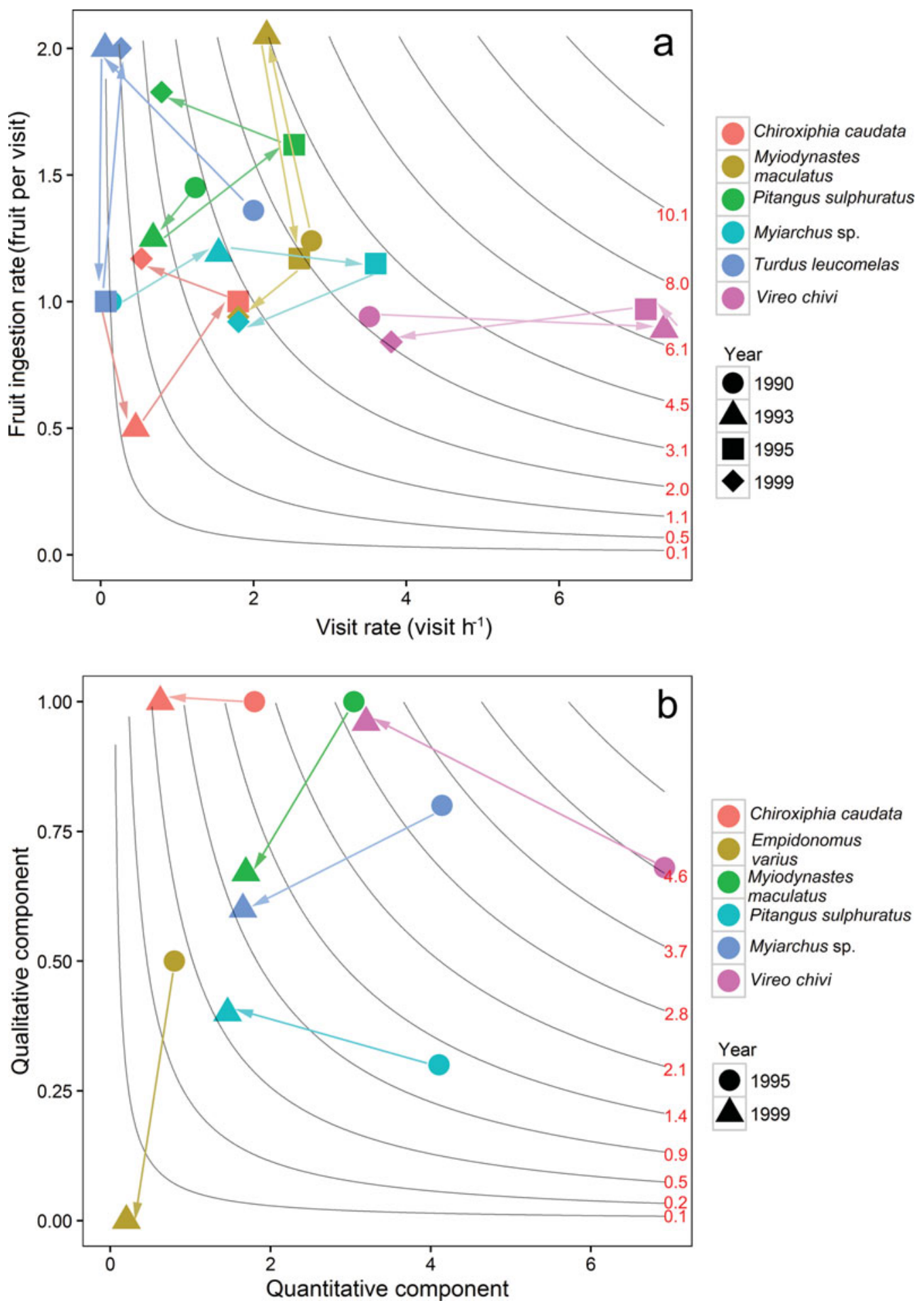

Figure 3. Annual variation in the quantitative component (a), and seed dispersal effectiveness (SDE) (b) among frugivorous bird species (represented by different colours) eating fruits of a Cabralea canjerana tree in a fragment of semideciduous Atlantic forest in south-eastern Brazil. The quantitative component is given by the visitation and fruit ingestion rates, while SDE is given by quantitative and qualitative (i.e. the probability of seed deposition in the forest fragment as estimated by the probability that a bird leaving the focal tree flew to the interior of forest fragment instead to the neighbouring urbanized area) components. Arrows indicate the temporal trajectories of bird species in the quantitative component and SDE landscapes. Isolines refer to values of the quantitative component and SDE indicated by red numbers to the right. Only species with non-zero values of either the quantitative subcomponents (a) or SDE (b) for all the study years are shown. 
plant over the other or, within a crop, one particular fruit among all the fruits available. Intracrop and seasonal variation in fruit chemistry and its consequences for fruit removal by primates have already been studied in Africa (Houle et al. 2007, Worman \& Chapman 2005). For the advancement of seed-dispersal research, it is particularly needed to access the temporal variation in the chemical composition of fruits and to know how such variation may influence SDE. For instance, fruit chemistry may vary in response to climate (e.g. water deficit; Roby et al. 2004), which, coupled with the discriminant abilities of birds and their preferences for certain fruit chemical profiles (Levey \& Martínez-del-Rio 2001), is an additional source of temporal variation in SDE.

The SDE of several bird species decreased from 1995 to 1999 (Figure 3b). Applied to the whole plant population, such temporal changes in SDE may have conservation and evolutionary implications, especially for plants with naturally reduced assemblages of seed dispersers or that have lost dispersal agents as a consequence of environmental degradation (Galetti et al. 2013). Such plants depend heavily on a few seed dispersers, and long-lasting changes in their SDE may have important consequences. Cabralea canjerana, for instance, has a substantial reduction in the number of seed dispersers following the fragmentation of its habitat (Pizo 1997). While in continuous forest $C$. canjerana has a much greater assemblage of dispersers, the complementary action of them potentially enhancing its establishment success by the dissemination of seeds along non-overlapping microhabitats (Pizo 1997, Rother et al. 2016), at our study site the migratory $V$. chivi is quantitatively the main disperser of $C$. canjerana. Therefore, severe reductions in the abundance of $V$. chivi impacting its SDE may affect the plant recruitment.

To conclude, we recall that the incorporation of the often-neglected natural history aspects of the interaction between plants and frugivores (agonistic interactions, variation in fruit size and fruit chemistry) is important to the comprehension of the causes of temporal and geographic variation in SDE, as recently also emphasized for network studies (Simmons et al. 2018).

\section{ACKNOWLEDGEMENTS}

We thank the staff of Mata de Santa Genebra who made possible our work at the reserve. Judite L. Guimarães kindly made the fruit chemical analyses. Part of the fieldwork was supported by a fellowship (\#92/1597-2) to MAP from the Fundação para Apoio à Pesquisa do Estado de São Paulo (FAPESP). PHSAC receives a $\mathrm{PhD}$ scholarship from the Coordenação de Aperfeiçoamento de Pessoal de Nível Superior (CAPES).

\section{LITERATURE CITED}

BLAKE, J. G. \& LOISELLE, B. A. 1991. Variation in resource abundance affects capture rates of birds in three lowland habitats in Costa Rica. The Auk 108:114-130.

BLENDINGER, P. G., GIANNINI, N. P., ZAMPINI, I. C., ORDOÑEZ, R., TORRES, S., SAYAGO, J. E., RUGERA, R. A. \& ISLA, M. I. 2015. Nutrients in fruits as determinants of resource tracking by birds. Ibis 157:480-495.

BLIGH, E. G. \& DYER, W. J. 1959. A rapid method of total lipid extraction and purification. Canadian Journal of Biochemistry and Physiology 37:911-917.

FRENCH, A. R. \& SMITH, T. B. 2005. Importance of body size in determining dominance hierarchies among diverse tropical frugivores. Biotropica 37:96-101.

GALETTI, M., GUEVARA, R., CÔRTES, M.C., FADINI, R., VON MATTER, S., LEITE, A. B., LABECCA, F., RIBEIRO, T., CARVALHO, C. S., COLLEVATTI, R. G., PIRES, M. M., GUIMARÃES, P. R., BRANCALION, P.H., RIBEIRO, M.C. \& JORDANO, P. 2013. Functional extinction of birds drives rapid evolutionary changes in seed size. Science 340:1086-1090.

GROEMPING, U. 2006. Relative importance for linear regression in R: the package relaimpo. Journal of Statistical Software 17:1-27.

HERRERA, C. M. 1985. Determinants of plant-animal coevolution: the case of mutualistic dispersal of seeds by vertebrates. Oikos 44:132141.

HERRERA, C. M. 1998. Long-term dynamics of Mediterranean frugivorous birds and fleshy fruits: a 12-year study. Ecological Monographs 68:511-538.

HORWITZ, W. 1975. Official methods of analysis. Association of Official Analytical Chemists/AOAC, Arlington. 1094 pp.

HOULE, A., CHAPMAN, C. A. \& VICKERY, W. L. 2007. Intratree variation in fruit production and implications for primate foraging. International Journal of Primatology 28:1197-1217.

HOWE, H. F. \& DE STEVEN, D. 1979. Fruit production, migrant bird visitation, and seed dispersal of Guarea glabra in Panama. Oecologia 39:185-196.

JORDANO, P. 1995. Spatial and temporal variation in the avianfrugivore assemblage of Prunus mahaleb: patterns and consequences. Oikos 71:479-491.

JORDANO, P. \& SCHUPP, E. W. 2000. Determinants of seed disperser effectiveness: the quantity component and patterns of seed rain for Prunus mahaleb. Ecological Monographs 70:591-615.

LEVEY, D. J. \& MARTÍNEZ-DEL-RIO, C. 2001. It takes guts (and more) to eat fruit: lessons from avian nutritional ecology. Auk 118:819-831.

MALE, T. D. \& ROBERTS, G. E. 2002. Defense of fruiting trees by birds in an Australian forest. Biotropica 34:172-176.

MCCONKEY, K. R., BROCKELMAN, W. Y. \& SARALAMBA, C. 2014. Mammalian frugivores with different foraging behavior can show similar seed dispersal effectiveness. Biotropica 46:647-651.

MORELLATO, L. P. C. \& HADDAD, C. F. B. 2000. Introduction: the Brazilian Atlantic Forest. Biotropica 32:786-792.

NATHAN, R. \& MULLER-LANDAU, H. C. 2000. Spatial patterns of seed dispersal, their determinants and consequences for recruitment. Trends in Ecology and Evolution 15:278-285. 
PENNINGTON, T. D. 1981. Flora neotropica: monograph number 28. Meliaceae. New York Botanical Garden, New York. 472 pp.

PIACENTINI, V. D. Q., ALEIXO, A., AGNE, C. E., MAURIĆIO, G. N., PACHECO, J. F., BRAVO, G. A., BRITO, G. R. R., NAKA, L. N., OLMOS, F., POSSO, S., SILVEIRA, L. F., BETINI, G. S., CARRANO, E., FRANZ, I., LEES, A. C., LIMA, L.M., PIOLI, D., SCHUNCK, F., DO AMARAL, F. R., BENCKE, G. A., COHN-HAFT, M., FIGUEIREDO, L. F. A., STRAUBE, F. C. \& CESARI, E. 2015. Annotated checklist of the birds of Brazil by the Brazilian Ornithological Records Committee/Lista comentada das aves do Brasil pelo Comitê Brasileiro de Registros Ornitológicos. Revista Brasileira de Ornitologia 23:90-298.

PIZO, M. A. 1997. Seed dispersal and predation in two populations of Cabralea canjerana (Meliaceae) in the Atlantic Forest of southeast Brazil. Journal of Tropical Ecology 13:559-578.

ROBY, G., HARBERTSON, J. F., ADAMS, D. A. \& MATTHEWS, M. A. 2004. Berry size and vine water deficits as factors in winegrape composition: anthocyanins and tannins. Australian Journal of Grape and Wine Research 10:100-107.

ROTHER, D. C., PIZO, M. A. \& JORDANO, P. 2016. Variation in seed dispersal effectiveness: the redundancy of consequences in diversified tropical frugivore assemblages. Oikos 125:336-342.

SAINO, N., AMBROSINI, R., RUBOLINI, D., VON HARDENBERG, J., PROVENZALE, A., HÜPPOP, K., HÜPPOP, O., LEHIKOINEN, A., LEHIKOINEN, E., RAINIO, K., ROMANO, M. \& SOKOLOV, L. 2011. Climate warming, ecological mismatch at arrival and population decline in migratory birds. Proceedings of the Royal Society of London B: Biological Sciences 278:835-842.

SCHAEFER, H. M., SCHMIDT, V. \& BAIRLEIN, F. 2003. Discrimination abilities for nutrients: which difference matters for choosy birds and why? Animal Behaviour 65:531-541.
SCHUPP, E. W. 1993. Quantity, quality and the effectiveness of seed dispersal by animals. Vegetatio 107:15-29.

SCHUPP, E. W., JORDANO, P. \& GÓMEZ, J. M. 2010. Seed dispersal effectiveness revisited: a conceptual review. New Phytologist 188:333353.

SIMMONS, B., SUTHERLAND, W. J., DICKS, L. V., ALBRECHT, J., FARWIG, N., GARCÍA, D., JORDANO, P. \& GONZÁLEZ-VARO, J.P. 2018. Moving from frugivory to seed dispersal: incorporating the functional outcomes of interactions in plant-frugivore networks. Journal of Animal Ecology. In press.

TELLERÍA, J. L., RAMIREZ, A. \& PÉREZ-TRIS, J. 2008. Fruit tracking between sites and years by birds in Mediterranean wintering grounds. Ecography 31:381-388.

TELLERÍA, J. L., CARRASCAL, L. M. \& SANTOS, T. 2014. Large-scale features affect spatial variation in seed dispersal by birds in juniper woodlands. Ecological Research 29: $13-20$.

THOMPSON, J. N. 2005. The geographic mosaic of coevolution. University of Chicago Press, Chicago. 425 pp.

WHEELWRIGHT, N. T. 1993. Fruit size in a tropical tree species: variation, preference by birds, and heritability. Vegetatio 107/108:163174.

WORMAN, C.O.D. \& CHAPMAN, C.A. 2005. Seasonal variation in the quality of a tropical ripe fruit and the response of three frugivores. Journal of Tropical Ecology 21: 689-697.

YAMAZAKI, Y., NAOE, S., MASAKI, T. \& ISAGI, Y. 2016. Temporal variations in seed dispersal patterns of a bird-dispersed tree, Swida controversa (Cornaceae), in a temperate forest. Ecological Research 31:165-176. 
Appendix 1. Quantitative and qualitative components of seed dispersal effectiveness of birds visiting a Cabralea canjerana tree in a fragment of semideciduous Atlantic forest in south-eastern Brazil. The qualitative component is given by the proportion of postfeeding flights of birds towards the interior of the forest fragment, likely a better place for seed deposition than the neighbouring urbanized area. Two similar, sometimes hard to identify species, Myiarchus ferox and M. swainsoni, are pooled as Myiarchus spp. Bird nomenclature follows Piacentini et al. (2015).

\begin{tabular}{|c|c|c|c|c|c|c|c|c|c|c|}
\hline & \multicolumn{8}{|c|}{ Quantitative component } & \multirow{2}{*}{\multicolumn{2}{|c|}{$\begin{array}{c}\text { Qualitative componen } \\
\text { Proportion of } \\
\text { departure flights }\end{array}$}} \\
\hline & \multicolumn{4}{|c|}{ Visitation rate $\left(\right.$ visit $\left.\mathrm{h}^{-1}\right)$} & \multicolumn{4}{|c|}{$\begin{array}{c}\text { Fruit intake rate } \\
\text { (fruit eaten per visit) }\end{array}$} & & \\
\hline & 1990 & 1993 & 1995 & 1999 & 1990 & 1993 & 1995 & 1999 & 1995 & 1999 \\
\hline Celeus flavescens & 0.0 & 0.0 & 0.2 & 0.3 & - & - & 2.5 & 1.0 & 0.5 & 1.0 \\
\hline Chiroxiphia caudata & 0.1 & 0.5 & 1.8 & 0.5 & 1.0 & 0.5 & 1.0 & 1.2 & 1.0 & 1.0 \\
\hline Manacus manacus & 0.1 & 0.8 & 0.3 & 0.0 & 1.0 & 1.2 & 1.0 & - & 1.0 & - \\
\hline Pachyramphus validus & 0.0 & 0.2 & 0.0 & 0.1 & - & 1.0 & - & 0.0 & - & 1.0 \\
\hline Tyrannus savana & 0.2 & 0.0 & 0.0 & 0.0 & 1.0 & - & - & 1.0 & - & - \\
\hline Tyrannus melancholicus & 0.1 & 0.0 & 0.5 & 0.1 & 1.0 & - & 2.3 & 1.0 & 0.0 & - \\
\hline Empidonomus varius & 0.1 & 0.1 & 0.8 & 0.2 & 1.0 & 2.0 & 1.0 & 1.0 & 0.5 & 0.0 \\
\hline Megarynchus pitangua & 0.0 & 0.1 & 0.5 & 0.0 & - & 2.0 & 1.0 & - & - & - \\
\hline Myiodynastes maculatus & 2.8 & 2.2 & 2.6 & 1.8 & 1.2 & 2.1 & 1.2 & 0.9 & 1.0 & 0.7 \\
\hline Pitangus sulphuratus & 1.2 & 0.7 & 2.5 & 0.8 & 1.5 & 1.3 & 1.6 & 1.8 & 0.3 & 0.4 \\
\hline Myiarchus spp. & 0.1 & 1.5 & 3.6 & 1.8 & 1.0 & 1.2 & 1.2 & 0.9 & 0.8 & 0.6 \\
\hline Elaenia flavogaster & 0.0 & 0.1 & 0.0 & 0.3 & - & 1.0 & - & 1.5 & - & 0.7 \\
\hline Turdus leucomelas & 2.0 & 0.1 & 0.1 & 0.3 & 1.4 & 2.0 & 1.0 & 2.0 & 0.0 & 0.0 \\
\hline Turdus rufiventris & 0.0 & 0.0 & 0.0 & 0.2 & - & - & - & 2.0 & - & 1.0 \\
\hline Vireo chivi & 3.5 & 7.4 & 7.1 & 3.8 & 0.9 & 0.9 & 1.0 & 0.8 & 0.7 & 1.0 \\
\hline Dacnis cayana & 0.2 & 0.8 & 0.7 & 1.7 & 0.0 & 0.0 & 0.0 & 0.0 & - & - \\
\hline Tangara cayana & 0.0 & 0.0 & 0.0 & 0.1 & - & - & - & 0.0 & - & 0.0 \\
\hline Thraupis sayaca & 0.2 & 0.1 & 0.5 & 0.1 & 1.0 & 0.0 & 1.0 & 0.0 & 0.0 & 0.0 \\
\hline Ramphocelus carbo & 0.0 & 0.0 & 0.3 & 0.1 & - & - & 0.0 & 0.0 & - & - \\
\hline Tachyphonus coronatus & 0.2 & 0.1 & 0.0 & 0.1 & 0.0 & 0.0 & - & 0.0 & - & 1.0 \\
\hline Saltator similis & 0.0 & 0.2 & 0.7 & 0.2 & - & 0.0 & 1.0 & 0.5 & 0.7 & - \\
\hline Coefficient of variation (\%) & 193 & 234 & 164 & 160 & 47.6 & 77.6 & 59.3 & 84.0 & 72.6 & 72.8 \\
\hline
\end{tabular}

